\title{
The Concept of “Datong” in Chinese Philosophy as an Expression of the Idea of the Common Good
}

\author{
Albert H.Y. Chen*
}

The concept of "datong" in Chinese philosophy was developed more than two millennia ago in the Confucian classics. It has been translated as "Great Unity", "Great Community”, "Great Universality”, "Great Similarity”, "Grand Harmony”, etc. In the "Liyun" section of Liji (the Book of Rites), the concept of "datong" was first introduced, and a distinction was drawn between the society of "datong" and that of "xiaokang” (translated as "Small Tranquility” or "Lesser Prosperity”).

In the early twentieth century, the great Chinese thinker and reformer Kang Youwei wrote a book entitled Datong shu (Book on the Great Community) in which he put forward an original and radical interpretation of "datong", drawing mainly upon both Liyun and another of the Confucian classics -- the Gongyang Commentary to the Spring and Autumn Annals which propounds a theory of progress in human history from the Age of Disorder to the Age of Ascending Peace and finally to the Age of Universal Peace.

This paper will analyze the concept of “datong” in Liyun and in Kang's Datong shu, and suggest that the concept is an expression of the idea of the common good in traditional Chinese social and political philosophy. It will examine and reflect on Kang's Datong shu and the elements of Confucianism, Buddhism, liberalism, utilitarianism, utopianism and socialism/communism that can be found in the book. It will also show that the ideology currently propounded by the Chinese Communist Party, including the ideas of the "preliminary stage of socialism" and the "xiaokang society", may be better understood in the light of the concept of "datong" in Chinese philosophy.

\section{I “Datong" in Liyun}

The term and concept of "datong" in the history of Chinese thought originates from the opening passage of the "Liyun" ("Evolution of Rites") chapter of Liji (the Book of Rites), one of the great books of Confucian classics. The Book of Rites is believed to have been complied by Confucian scholars more than two millennia ago in the Han dynasty. This passage on "datong" has been described as "one of the most celebrated in Confucian literature” (de Bary, 1960, p. 175). It reads as follows. ${ }^{1}$

\footnotetext{
* Faculty of Law, University of Hong Kong.

1 The following translation is taken from de Bary, 1960, pp. 175-176.
} 
Once Confucius was taking part in the winter sacrifice. After the ceremony was over, he went for a stroll along the top of the city gate and sighed mournfully. He sighed for the state of Lu.

His disciple Yen Yen [Tzu Lu], who was by his side, asked: 'Why should the gentleman sigh?'

Confucius replied: 'The practice of the Great Way, the illustrious men of the Three Dynasties - these I shall never know in person. And yet they inspire my ambition! When the Great Way was practiced, the world was shared by all alike. The worthy and the able were promoted to office and men practiced good faith and lived in affection. Therefore they did not regard as parents only their own parents, or as sons only their own sons. The aged found a fitting close to their lives, the robust their proper employment; the young were provided with an upbringing and the widow and widower, the orphaned and the sick, with proper care. Men had their tasks and women their hearths. They hated to see goods lying about in waste, yet they did not hoard them for themselves; they disliked the thought that their energies were not fully used, yet they used them not for private ends. Therefore all evil plotting was prevented and thieves and rebels did not arise, so that people could leave their outer gates unbolted. This was the age of Grand Unity.

Now the Great Way has become hid and the world is the possession of private families. Each regards as parents only his own parents, as sons only his own sons; goods and labor are employed for selfish ends. Hereditary offices and titles are granted by ritual law while walls and moats must provide security. Ritual and righteousness are used to regulate the relationship between ruler and subject, to insure affection between father and son, peace between brothers, and harmony between husband and wife, to set up social institutions, organize the farms and villages, honor the brave and wise, and bring merit to the individual. Therefore intrigue and plotting come about and men take up arms. Emperor Yu, kings Tang, Wen, $\mathrm{Wu}$ and Cheng and the Duke of Chou achieved eminence for this reason: that all six rulers were constantly attentive to ritual, made manifest their righteousness and acted in complete faith. They exposed error, made humanity their law and humility their practice, showing the people wherein they should constantly abide. If there were any who did not abide by these principles, they were dismissed from their positions and regarded by the multitude as dangerous. This is the period of Lesser Prosperity.

The passage thus portrays two forms of society, that of Grand Unity (datong) and that of Lesser Prosperity (xiaokang). Both are good, with datong being the greater good or the best and xiaokang being the lesser good or the second best. Datong is where the Great Way prevails. It is usually interpreted to refer to a Golden Age in prehistoric times (such as the times of the rulers Yao and Shun), as the dominant Confucian view 
of history or prehistory is that the ideal society existed in times immemorial but declined subsequently. The opening sentence of Confucius' saying in the passage refers also to the Three Dynasties. They are the dynasties of Xia, Shang and Zhou in ancient Chinese history (which followed the times of Yao and Shun). The "illustrious men of the Three Dynasties" referred to in the first paragraph of Confucius' saying actually include the "six rulers" (Emperor Yu, kings Tang, Wen, Wu and Cheng and the Duke of Chou) referred to in the second paragraph in the discussion of xiaokang. Thus the opening sentence of Confucius' saying implies that society in Confucius' time conformed to the criteria of neither datong nor xiaokang; even the lesser ideal of xiaokang was unable to be realized in his time.

It may be seen from the detailed description of xiaokang society in the passage that it actually practices the basic teachings of Confucianism. For example, Confucianism emphasizes the "five cardinal relationships" as the foundation of ethics - the relationships between father and son, ruler and subject, husband and wife, elder brother and younger brother, friend and friend. The li (rites, rituals and norms of propriety) is also stressed by Confucianism as the indispensable basis for social order and social life. In the passage on xiaokang, it is said that "Ritual and righteousness are used to regulate the relationship between ruler and subject, to insure affection between father and son, peace between brothers, and harmony between husband and wife, to set up social institutions, ... all six rulers were constantly attentive to ritual”. This reflects the centrality of the $l i$ and of the cardinal human relationships in the xiaokang society. Other Confucian virtues, such as righteousness, faithfulness, humanity (benevolence) and humility, are also practiced in xiaokang society: "all six rulers were constantly attentive to ritual, made manifest their righteousness and acted in complete faith. They exposed error, made humanity their law and humility their practice”.

If Confucian teachings are already practiced in the xiaokang society, why is it not the ideal society? One sentence in the middle of the passage on xiaokang strikes the reader: "Therefore intrigue and plotting come about and men take up arms." Thus establishment of the $l i$, of social institutions and the obligations associated with the cardinal human relationships cannot ensure social harmony and peaceful co-existence among human beings. There will inevitably be competition, struggles and even wars among them. The roots of the problem seem to lie with what is identified at the beginning of the passage on xiaokang: "the world is the possession of private families. Each regards as parents only his own parents, as sons only his own sons; goods and labor are employed for selfish ends.” These circumstances contrast sharply with those in the datong society: "the world was shared by all alike. The worthy and the able were promoted to office and men practiced good faith and lived in affection. Therefore they did not regard as parents only their own parents, or as sons only their own sons."

In xiaokang, "the world is the possession of private families." This may be regarded as a reference to dynastic rule, under which the monarch is succeeded by his son and 
the monarch regards the state as his family possession, as contrasted with the datong world in which all people share in the enjoyment of the benefits of social cooperation and the ruling elite is chosen on the basis of their merits and abilities rather than being a hereditary aristocracy ("hereditary offices and titles are granted by ritual law" in xiaokang society). Another key difference between datong and xiaokang is that whereas in xiaokang, people care only about themselves and their family members, in datong, people care about all fellow members of society. Thus the welfare of all is taken care of in the datong society: "The aged found a fitting close to their lives, the robust their proper employment; the young were provided with an upbringing and the widow and widower, the orphaned and the sick, with proper care. Men had their tasks and women their hearths.” A third major difference between datong and xiaokang is that whereas in xiaokang, people use their property and invest their labor for their own benefits ("goods and labor are employed for selfish ends"), in datong property and labor are both devoted to serving the public good: "They hated to see goods lying about in waste, yet they did not hoard them for themselves; they disliked the thought that their energies were not fully used, yet they used them not for private ends."

Datong society is therefore one in which everybody is devoted to serving the common good of all instead of seeking only or mainly to benefit themselves and their families. Datong may thus be regarded as a society where the common good prevails, or the embodiment of the idea of the common good itself. To use Confucian language, datong is a society in which the Confucian virtue of ren (benevolence or love) is most fully practiced by members of society. According to Confucianism as developed by Confucius and Mencius, the practice of ren naturally begins with one's family members - hence the importance of the social relationships of father and son, elder brother and younger brother, and husband and wife and the cardinal virtue of filial piety. Beginning with the circle of one's relatives, the practice of ren should then extend to include more and more people, eventually embracing all under Heaven (Liang, 1968, chs. 2-3).

\section{II “Datong” in Kang Youwei's Thought}

Approximately two millennia after the concept of "datong" was first formulated in the Liyun chapter of the Book of Rites, "datong” came again to the fore of Chinese political and social thought as Chinese thinkers confronted the challenges of the West and of modernization. Dr Sun Yat-sen, founder of the Republic of China established in 1912, was well-known for his high evaluation of the Liyun datong passage, and had said that the purpose of the Three People's Principles ${ }^{2}$ - the political doctrine developed by him as the ideological foundation of the Republic of China - was to bring about datong (Zhang, 1988, p. 6). Upon his death the phrase "tianxia weigong" ("the world is shared by all alike", a phrase taken from the Liyun datong passage), much loved by him when he was alive, was inscribed on his tomb. It is noteworthy

\footnotetext{
${ }^{2}$ The three principles are the Principle of People's National Consciousness, the Principle of People's Rights, and the Principle of People's Livelihood.
} 
that datong was also a favorite concept of his political adversary, Kang Youwei, who had opposed the revolution but advocated peaceful constitutional reform and the establishment of a constitutional monarchy. Kang was a Confucian thinker, a political activist and an ardent advocate of China's political and social reform. In one of his books, Datong shu, completed in 1902 (Hsiao, 1975, p. 480) but only published posthumously in 1935 (Thompson, 1958, p. 31), he put forward an original and radical interpretation of datong, to which most of the remainder of this paper will be devoted.

Before going into the central thesis of Datong shu itself, two important ingredients or "building blocks" of that thesis may first be introduced. They are the Confucian doctrine of ren (benevolence or love), and the theory of history elaborated in He Xiu's work (written the Latter Han dynasty) on the Gongyang Commentary to the Spring and Autumn Annals.

Ren is one of most important virtues or values preached by Confucianism. It may be translated as benevolence or love, and refers to feelings of humanity, sympathy and empathy among human beings. The significance of ren as an ultimate moral principle is demonstrated by the following passage from Confucius' Analects (book XV, section 9, trans. D.C. Lau): "For Gentlemen of purpose and men of benevolence (ren) while it is inconceivable that they should seek to stay alive at the expense of benevolence, it may happen that they have to accept death in order to have benevolence accomplished.” As pointed out by Chan Wing-tsit (1967, p. 356), a leading authority on Chinese philosophy,

This love [ren] is universal in nature, but there must be distinctions, that is, an order or gradation in application, beginning with the love for one's parents. ... Jen [ren] is extended to include not only all human beings but the universe in its totality, man and the universe thus forming one body. ... Jen is not merely an attitude or consciousness but an active and dynamic relationship between men and all things. ... Jen is the foundation of all goodness, the 'mind of man,' and the source of everything produced in the universe. ... As such, jen is both ethical and metaphysical.

Drawing on the long tradition of Confucian thinking on ren, Kang Youwei developed his own interpretation of ren, a concept to which he attached central importance in his system of thought. Liang Qichao, Kang's pupil who was as famous as Kang as a leading intellectual and political activist in early twentieth-century China, wrote in his biography of Kang: "The philosophy of Master K’ang is the philosophy of the school of universal love. In his doctrine he considered jen [ren] as the one fundamental principle, believing that the foundation of the world, the birth of all creatures, the existence of states, and the development of moral institutions are all based on it.” (Chan, 1967, p. 357) 
What then is the essence of ren as understood by Kang? Drawing upon Mencius, Kang emphasized that ren is the compassionate mind or "the mind that cannot bear to see the suffering of others" (burenren zhixin).

According to Mencius,

whoever is devoid of the heart of compassion is not human, whoever is devoid of the heart of shame is not human, whoever is devoid of the heart of courtesy and modesty is not human, and whoever is devoid of the heart of right and wrong is not human. The heart of compassion is the germ of benevolence [ren]; the heart of shame, of dutifulness; the heart of courtesy and modesty, of observance of the rites; the heart of right and wrong, of wisdom. Man has these four germs just as he has four limbs. (Mencius, book II, part A, section 6, trans. D.C. Lau)

This passage suggests that ren is one of four basic virtues that define humanity. But as pointed out by Chan Wing-tsit (1967, pp. 358-9),

In K'ang's philosophy, on the contrary, jen is not a particular virtue but the general one, the foundation of all that is good and true. The concept of jen as the general virtue goes back to Confucius. What is new with $\mathrm{K}$ 'ang is to interpret the feeling of compassion, not in the sense of a particular virtue as Mencius had it, but as the general virtue.

Apart from the doctrine of ren, another intellectual resource that Kang drew on in his work on datong is the scholarship on the philosophy of history derived from the Gongyang Commentary to the Spring and Autumn Annals. Such a philosophy was clearly formulated by the Confucian scholar He Xiu (129-182 A.D.) in the Latter Han dynasty, author of Chunqiu Gongyang jiegu (Explanations on the Gongyang Commentary to the Spring and Autumn Annals (Chunqiu)). In contrast with the conventional view in the Chinese tradition that the written history of China consists of cycles of order and disorder, He Xiu derived from Chunqiu Gongyang an interpretation of history as consisting of "Three Ages" - the Age of Disorder (shuailuan shi), followed by the Age of Ascending Peace (shengping shi, also translated as Age of Increasing Peace-and-Equality), and finally followed by the Age of Universal Peace (taiping shi, also translated as Age of Complete Peace-and-Equality). He Xiu interpreted the history of the Lu state as told in Chunqiu as unfolding in accordance with the three stages, which comprise not only a chronological dimension but a spatial dimension as well - with more and more territories being brought within the sphere of civilization in the course of time. According to this theory or philosophy of history, there is and can be social progress in the course of time, with society at a lower level of the development of culture or civilization evolving to a higher level of such development.

The originality and genius of Kang Youwei's thought is to combine the doctrine of ren 
and the Gongyang theory of history to produce a vision of human historical progress in stages in the course of which the value or ideal of ren is realized to increasing degrees, and to associate the highest degree of realization of ren with the ancient concept of datong. The increasing realization of ren is accompanied by an advancing level of culture, education and moral cultivation among the people, ${ }^{3}$ and the gradual reduction of inequality in society. This line of thinking is not only evident in Datong shu itself but also in Kang's other writings. In Mengzi wei (Esoteric Meanings of Mencius), he wrote:

Confucius instituted the scheme of three stages. In the Age of Disorder jen [ren] cannot be extended far and therefore people are merely affectionate to their parents. In the Age of Approaching Peace, jen is extended to one's own kind and therefore people are humane to all people. In the Age of Universal Peace [Great Unity or datong], all creatures form a unity and therefore people love all creatures as well. There is distinction and graduation in jen because there are stages in historical progress. (translation in Chan, 1967, p. 367)

The following passage from Kang's Liyun zhu (Commentary on Liyun), which may certainly be considered radical from the traditional Confucian perspective, anticipates our discussion below of Kang's Datong shu itself:

Now to have states, families, and selves is to allow each individual maintain a sphere of selfishness. This infracts utterly the Universal Principle (gongli) and impedes progress. ... Therefore, not only states should be abolished, so that there would be no more struggle between the strong and the weak; families should also be done away with, so that there would no longer be inequality of love and affection [among men]; and, finally, selfishness itself should be banished, so that goods and services would not be used for private ends. ... The only [true way] is sharing the world in common by all (tienxia weigong) ... To share in common is to treat each and every one alike. There should be no distinction between high and low, no discrepancy between rich and poor, no segregation of human races, no inequality between sexes. ... All should be educated and supported with the common property; none should depend on private possession. ... This is the way of the Great Community [datong] which prevailed in the Age of Universal Peace. (translation in Hsiao, 1975, p. 499)

In order to understand the further details of Kang's vision of datong in the Age of Universal Peace, let us now turn to his book Datong shu itself. The book consists of ten parts, with each part being divided into several chapters. Part I of the book introduces the core ideas of the book. The title of part I is "Entering the world and seeing universal suffering”. The first section of this part is entitled "Introduction: Men have compassionate natures”. Probably influenced by Buddhist perspectives, it

\footnotetext{
${ }^{3}$ Zhang Xiang (2009) stresses the importance of culture and education (wenjiao) or cultivation (jiaohua) in Kang’s philosophy of progress towards datong.
} 
underscores the universality of the experience of suffering in the world. "[W]e see that the whole world is but a world of grief and misery, all the people of the whole world are but grieving and miserable people”. (Thompson, 1958, p. 63 (D63); subsequent page references to Datong shu, which will be abbreviated Dx (x being the page number), are also references to Thompson's translation of Datong shu.) But human beings seek happiness and do not want to suffer. "[U]nder the firmament, all who have life only seek pleasure and shun suffering.” (D71) Kang goes on to make the utilitarian argument that the distinction between good and evil depends on whether happiness is promoted and suffering is minimized. "The establishment of laws and the creation of teachings [of the Way] which cause men to have happiness and to be [entirely] without suffering: [this] is the best [form] of the Good.” (D71)

In Kang's view, human beings are not indifferent to the suffering of others. "I myself am a body. Another body suffers; it has no connection with me, and yet I sympathize very minutely. Moving about I am distressed; sitting I reflect [on it].” (D63) This is because humans have the "compassionate mind". (D64) The compassionate mind is part of the essence of humanity. "[I]f men sever what constitutes their compassionate love, their human-ness will be annihilated.” (D64) On the other hand, the more we understand what is really going on in the world, the greater will be our compassion for others. "[T]hose whose perceptiveness and awareness is great, their jen-mind is also great. Boundless love goes with boundless perceptiveness.” (D67)

Turning back to the subject of suffering and happiness, Kang points out that individuals' happiness is consistent with, and, indeed, dependent on human beings' sociality and solidarity. "To enjoy being in groups, and to hate solitude, to mutually assist and mutually help, is what gives pleasure to man's nature. Therefore the mutual intimacy, mutual love, mutual hospitality, and mutual succouring of fathers and sons, husbands and wives, elder and younger brothers - which is not altered by considerations of profit or loss, or of difficulties - are what give pleasure to man." (D69)

In Kang's view, social institutions such as the family and the state were established by the sages - "persons of jen" (D63) - in ancient times for the benefit of mankind. "The sages, because of what gave pleasure to man's nature, and to accord with what is natural in matters human, then made the family law to control them. They said the father is merciful, and the son filial; the elder brother is friendly, the younger brother respectful; the husband is upright, the wife complaisant." (D69) Similarly, "[t]he sages, because of what man's nature cannot avoid, and to accord with what is natural in matters human and in the conditions of the times, on their behalf established states, tribes, rulers, ministers, and laws of government. This method is simply [for the purpose of] enabling man to avoid suffering, and nothing else.” (D70)

While affirming the utility and legitimacy of such social institutions, Kang also points out that they are contingent upon the circumstances of the time, and that institutions 
originally established for legitimate purposes may in their practical operation be oppressive and produce suffering.

Even if there be sages who establish the laws, they cannot but determine them according to the circumstances of their times, and the venerableness of customs. The general conditions which are in existence, and the oppressive institutions which have long endured, are accordingly taken as morally right. In this way, what were at first good laws of mutual assistance and protection end by causing suffering through their excessive oppressiveness and inequality. (D72)

Kang then refers to the theory of the "Three Ages" - which he attributed to Confucius himself - as providing a solution to this problem. (D72) Social institutions can and will evolve in the course of time so as to achieve rising levels of development and perfection. "[F]ollowing [the Age of] Disorder, [the world] will change to [the Ages, first] of Increasing Peace-and-Equality, [and finally], of Complete Peace-and-Equality; following the Age of Little Peace-and-Happiness, [the world] will advance to [the Age of] One World.” (D72) Kang believed that he lived in the Age of Disorder, but he was able to work out how the "Way of One World of Complete Peace-and-Equality" was to be realized. (D72)

Kang works out this Way by first identifying and classifying the types or forms of suffering in the world, then tracing their causes or sources, and then designing the remedies. Kang identifies six kinds of suffering which he discusses in six separate chapters in part I of the book. Each of the six categories is analyzed and further divided into sub-categories. The six categories are "sufferings from living", "sufferings from natural calamities", "sufferings from the accidents of human life", "sufferings from government”, "sufferings from human feelings", and "sufferings from those things which men most esteem" (D73-4). Kang believed that most sufferings are ultimately attributable to the existence of nine boundaries (jie, alternatively translated as "distinctions”) (D74-5): (1) "nation-boundaries” (“division by territorial frontiers and by tribes”); (2) “class-boundaries” (“division by noble and base, by pure and impure”); (3) “race-boundaries” (“division by yellow, white, brown and black [skin types]”); (4) "sex-boundaries” (“division by male and female”); (5) "family-boundaries" ("the private relationships of father and son, husband and wife, elder and younger brother”); (6) "occupation-boundaries” ("the private ownership of agriculture, industry, and commerce”); (7) "disorder-boundaries" ("the existence of unequal, unthorough, dissimilar, and unjust laws"); (8) "kind-boundaries" ("the existence of a separation between man, and the birds, beasts, insects, and fish”); and (9) “suffering boundaries” (“[this means], by suffering, giving rise to suffering”).

Kang then states that "[t]he remedy for suffering lies, therefore, in abolishing these nine boundaries.” (D75) Each of the remaining parts of his book (parts II to X) is about the abolition of one of the nine boundaries. In Kang's view, all the nine boundaries will have been completely dissolved in the datong world of the Age of 
Complete Peace and Equality. Kang's portrait of this world in Datong shu has been rightly described as "the most imaginative utopian construct in Chinese intellectual history" (Hsiao, 1975, p. 500) ${ }^{4}$ and "the most notable work of its kind which has yet been produced, either in West or East.” (Thompson, 1958, p. 55) It is a vision of the common good of humankind - and not just the common good of the Chinese people ${ }^{5}$ -- inspired by traditional Chinese philosophy at a crucial historical moment when this tradition of thought first came into contact with modern Western thought. It also represents a radical reinterpretation of traditional Confucian philosophy. ${ }^{6}$

In Kang's datong world (Thompson, 1958), the family, private property, the state and social classes as we understand them will all cease to exist. The world will no longer be divided into sovereign nation-states but will be administered by a world government. The planet Earth will be divided into administrative districts of equal size, each of which will practice local democratic self-government. There will be complete equality between men and women, and society will no longer be divided into classes. The enjoyment of property will be shared in common, and economic activities will not be for private gain but will be directed to the common good. The functions of the family as a social institution will be taken over by public institutions such as nurseries and schools, which will take charge of the rearing and education of children, as well as hospitals for the sick and institutions for the aged. Marriage will no longer be a legal and social union intended to be permanent but will be a renewable short-term contract. Homosexuals may practice their way of life as they wish. Euthanasia will be allowed. Animals will not be treated cruelly, and in the final stage of the evolution of the datong world, they will no longer be killed for food, but vegetarianism will be practiced by humankind. There will be no social distinctions between people, except that persons of great ren or knowledge will be given badges of honor to wear. In the datong world, the highest attainment in life will be the self-cultivation and practice involved in seeking spiritually enlightenment and becoming buddhas.

Although several crucial components of Kang's datong world are reminiscent of the communist society postulated by Karl Marx as the eventual goal of historical development and social evolution, there are fundamental differences between Kang and Marx in terms of their basic premises and the dynamics of social evolution as envisaged by them (Thompson, 1967). Marx emphasized people’s “selfish” material or economic interests as members of particular social classes; Kang believed that all

\footnotetext{
${ }^{4}$ For a comparison of Kang's utopianism and utopianism (including Marxism) in Western thought, see Malmqvist (1991).

${ }^{5}$ Wang Hui (2008, chap. 7) stresses the universalism in Kang's thought. He also identifies in Kang's thought a tension between the universalist logic of datong and the logic of strengthening the Chinese nation (and rescuing it from its weak position in the world, particularly in face of the Western powers and Japan).

${ }^{6}$ Chang Hao (2002, pp. 174-204) points out the radical nature of Kang's interpretation or reinterpretation of Confucianism.
} 
human beings have the compassionate mind, and caring about others is part of the essence of being human. Marx considered class division to be the fundamental division in society; Kang identified class division as merely one of the nine "boundaries" which give rise to struggles, conflicts and suffering, and in his thought other divisions such as those between the sexes, between racial or ethnic groups, or between nation-states are equally if not more important. Marx believed that class struggles and violent revolutions are necessary and inevitable for the purpose of realizing communism; Kang suggested that the evolution towards the datong world of the Age of Complete Peace-and-Equality is a natural, gradual and spontaneous process in which ren will be practiced to increasing degrees. It is also a process in which rising levels of culture or civilization, education, moral cultivation, awareness and enlightenment among human beings in society will be achieved. ${ }^{7}$

Some of Kang's proposals for the datong world are easy to understand given his faith in ren and his utilitarian inclinations. For example, the establishment of a world government will put an end to wars which have been one of the important causes of suffering in human history. Recognizing homosexuals' rights and permitting euthanasia may also be understood as being for the purpose of reducing unnecessary suffering and maximizing the possibility of happiness. In developing these ideas and others such as women's rights, gender equality, democratic self-government and humane treatment of animals, Kang was indeed most progressive and well in advance of the dominant values of his times (particularly in China, which at the end of the $19^{\text {th }}$ century lagged behind the West in social, political and intellectual modernization). Indeed, some of his "utopian” ideas, surely fanciful in China at his time, have today been implemented in parts of the world, and in other parts of the world are in the process of being implemented - more than a century after Kang wrote.

Take the example of the treatment of animals, which is dealt with in part IX of the book, entitled "abolishing boundaries of kind, and loving all living [things]". Kang points out that "man is merely one species of creatures" (D264), and the distinction between humans and other living things is a distinction in "kind", which "is no more than a distinction of appearance and physique” (D264). Writing about domesticated animals, Kang points out that "[w]hen we consider that they are not far removed from man in intelligence, that they too have feelings of terror and pain, that they are not a threat to our survival or essential to our diet, then it is against natural principles and the greatest of uncompassion to kill them.” (D266) However, Kang was of the view that the Buddhist prohibition against the killing of animals "cannot be carried out at present. The Way of Confucius is a progress in three stages: loving one's kin, loving all people, and finally loving all creatures. The stages correspond [of course] to the Three Ages.” (D266) Kang believed that "gradual progress” (D267) can be achieved, and even after the world has entered the datong era, there will still be three separate stages of development as far as the relationship between mankind and other animals is concerned. In first stage, mankind will refrain from killing animals which are

\footnotetext{
7 See note 3 above.
} 
“intelligent and useful” (D267). "[T]he [stage in which there is still] eating of flesh and killing of living [creatures] is One World's [datong's] Age of Disorder; [the stage in which] electrical machines [are used] to slaughter animals is One World's Age of Increasing Peace-and-Equality; [the stage in which] killing is prohibited and the desire [to kill and eat animals] is ended is One World's Age of Complete Peace-and-Equality.” (D267)

Kang's view about the phased implementation of benevolence for animals is consistent with and an integral part of his philosophy of gradual progress, which not only prescribes what is progressive but also emphasizes that it would not be appropriate, and may even be counter-productive, to attempt to implement what is suitable for the Age of Complete Peace-and-Equality in an earlier age (Zeng, 2009, p. 249). ${ }^{8}$ Kang himself well realized that his prescriptions for the Age of Complete Peace-and-Equality were so radical that if immediately publicized the impact on the society of his time would not be positive. That was why Kang never published the full text of Datong shu during his lifetime (Li, 1990, pp. 174, 177). Thus Kang was only radical in his thinking about humanity's distant future; in his life, actions and political advocacy, he was much more conservative than many of his contemporaries (Spence, 1981). Indeed, he opposed the Chinese revolutionaries' attempt to overthrow the Manchu dynasty, and proposed instead the establishment of a constitutional monarchy. This was consistent with his theory of political development (Zeng, 2009, pp. 247, 253; Wang Rongzu, 1988, p. 40): the political systems that correspond to the Age of Disorder, Age of Increasing Peace-and-Equality and Age of Complete Peace-and Equality are respectively absolute monarchy, constitutional monarchy and democratic republicanism. Kang believed that China's conditions at his time were such that democratic republicanism would be premature.

The single most radical and controversial part of Kang's thought about datong concerns the abolition in the datong world of the family as a social institution. Given that traditional Confucian ethics value human relationships within the family above anything else and privilege filial piety and other virtues practiced between family members, how or why did Kang come up with this radical idea? To answer this question, part VI of the book deserves close examination. It is entitled "abolishing family boundaries and becoming 'Heaven's people”" (D169). It elucidates the basic principles of the family as propounded by Confucianism, points out the positive contribution they have made to Chinese society in the course of history, and yet argues that they have to be superseded in the datong world.

Kang begins part VI of the book by pointing out that "love of the parents for their offspring is fundamental to all life" (D169). Such love is "spontaneous" and "is the Heaven-[conferred] (or Natural-) nature, the root of jen." (D169) "The family is the basic institution for all human beings throughout the world. Upon the family we

\footnotetext{
${ }^{8}$ See also a passage in Kang's commentary on Liyun, in Mengzi wei, Liyun zhu, Zhongyong zhu (1987),
} pp. 241-2. 
depend for protection, support, and spiritual solace from the cradle to the grave." (D173) As regards filial piety, Kang suggests that this is based on a fundamental moral principle of requital for favors received. "No grace, no virtue, can compare with those of parents, to whom we owe the very fact of our existence. ... The principle of requital is a universal, unchangeable principle. Since our greatest obligation is to our parents, our greatest responsibility is to repay this debt. Confucius emphasized filiality, considering this to be simply the requital of that debt.” (D173-4) Kang believes that Confucian family ethics and Chinese social practices relating to the family and clan "enacted by Confucius for the Age of Disorder ... [are] very conducive to propagation and to consolidation into groups of like kinds" (D171), and have made significant contributions to Chinese civilization and its population growth. "[T]he Chinese system is the ultimate development of the family.” (D171)

Kang goes on to point out that "the family is a necessity of the Ages of Disorder and Increasing Peace-and-Equality [because it is "an institution essential to mutual support among men” (D182)], but is the most detrimental thing to [attaining] to the Age of Complete Peace-and-Equality. ... if we wish to attain the beauty of complete equality, independence, and the perfection of [human] nature, it can [be done] only by abolishing the state, only by abolishing the family.” (D183) What then is wrong with the family as a social institution to be maintained permanently? Several strands of reasoning may be discerned in part VI. First, Kang points out that filial piety, though a good ideal, is often not practiced (D173) and is no more than "an empty ideal” (D176). "Those who can resist the call of their own desires and care for their parents instead are but few." (D176) "[T] he reason filiality is difficult and [parental] compassion is easy, is due entirely and solely to opinions. [If parents and children] are unable to hold the same opinions, then they are unable to live together” (D179). Secondly, Kang highlights "the sufferings of members of a family who are constrained to live together" (D179), which include those caused by discord and quarrels - "inevitable consequences of forcing several human beings to live together, ... with all their prejudices, special affections, dislikes, frailties, and cross-purposes. This situation is worst in China, because of its large-family system” (D179). Thirdly and most significantly, Kang associates care and concern for one's family members with selfishness and considers the family as a social institution an impediment to the realization of a society in which everyone is devoted to the common good and all persons, whether male or female, enjoy equality and autonomy and is well taken care of by society:

If there are families, then there is selfishness. (D180) ... The family is too exclusive: parents try to give the best only to their own children. Since there are very few wealthy and high-class families in comparison to the poor and low-class families, and each gives only to its own as best it can, it follows that there can never be any universal equality, and that there will always be only a few in a nation who are strong, intelligent, good, and brave, and vast numbers who are weak, stupid, vicious, and cowardly. (D179-180) ... If people hold selfishly to 
their own families, then private property cannot be used as public property, and there is nothing whereby to publicly support the people of the whole world; but there are numerous poor and suffering people. (D182) ... If people all hold selfishly to their own families, then there cannot be much of a levy for public expenditures to provide public benefits. (D182)

Kang anticipates and responds to one possible fundamental objection to his idea about the abolition of the family. "It may be said that for the parents to be with their children is [inherent in our] Heaven [-conferred] nature; and that to give them up is contrary to natural principles. And yet nowadays in France, America, and Australia there are many illegitimate children. ... After men and women are free, there will necessarily be many illegitimate children.” (D186) Kang thus implies that human nature is not such that having a family and living within a family is essential to its realization. But the abolition of the family is not a goal that can be or should be immediately achieved. "[T]here is a Way to get there. Gaining it will be gradual; [we must proceed] in orderly sequence to perfect it.” (D184)

\section{Reflections on datong and the common good}

It may be seen from the above that both the Liyun section of the Book of Rites written more than two millennia ago and Kang Youwei's Datong shu written more than a century ago use the concept of datong to express the idea of the common good in human society. The philosophy of datong may be understood as a Chinese contribution to universal thinking about the common good. In Liyun, datong, in contrast to xiaokang, refers to an ideal state of human social existence probably in the mythical Golden Age of the remote past. In Datong shu, the same term datong is used to describe an ideal world in the distant future, when social evolution has progressed to the Age of Complete Peace-and-Equality. In both of these datong worlds, "the world is shared by all alike" ("tianxia weigong"). Human pursuits are directed to the common good of all rather than to the satisfaction of selfish or private desires. Property is held in common. The well-being of all in society is well taken care of. The practice of ren is not confined to one's family members but extends to all in a kind of universal brotherhood/sisterhood.

Whereas the discussion of datong in Liyun is only one paragraph in length, Kang Youwei elaborates the theoretical foundation and practical details of the datong world in his book-length work on the subject. The theoretical foundation includes the Confucian doctrine of ren, interpreted by Kang as the compassionate mind, and the Gongyang philosophy of history as progress unfolding in Three Ages. Now insofar as ren means love for others and care and concern for others' welfare, it is necessary to develop criteria for determining what is good for others and what their well-being consists of. Here Kang adopts the utilitarian criterion that happiness or pleasure is good and pain and suffering bad, with the qualification that human nature is such that individuals' happiness is closely related to and dependent on their sociality and 
solidarity within a community.

Thus human nature as ren seeks the realization of the common good of all, which consists of the minimization of suffering and maximizing the possibility of happiness. The philosophy of history as progress suggests that it is possible for ren to be realized to increasing degrees in the course of social evolution and historical development. The question then is how suffering is to be minimized and happiness maximized. Influenced by Buddhist thinking, Kang perceives suffering as a universal phenomenon inextricably linked to human existence. He then develops the original idea that suffering is a result of the existence of the "nine boundaries", the gradual dissolution of which will usher in the datong world of the Age of Complete Peace-and-Equality. The theory of the "nine boundaries" and their dissolution is thus Kang's most important contribution to the Chinese tradition of datong thinking.

Kang's thesis is that the ultimate realization of the common good in human social existence consists of the dissolution of the "nine boundaries", which includes, among other things, the abolition of sovereign nation-states and the establishment of a world government with democratic autonomy at local levels, the disappearance of social classes and of private property, and the transfer of the functions of the family to publicly established institutions, which will take care of all aspects of individuals' welfare from cradle to grave. Social, economic and political equality will be achieved, and individuals will enjoy maximum autonomy and freedom, including, for example, freedom from family obligations, freedom to change marriage partners, freedom to pursue a homosexual lifestyle, freedom to pursue spiritual development, and freedom or right of euthanasia. ${ }^{9}$ Even animals' right to life and to humane treatment will receive recognition. Hence Kang's philosophy, built upon a synthesis of Confucianism, Buddhism, utilitarianism, and the conception of social evolution and progress, points towards an utopian future with elements of socialism or communism and liberalism.

Kang's datong world is a far cry from the world of sovereign nation-states and global capitalism that exists today, with all its gross social, economic and political inequalities among different states and among different classes in the same state, and the extreme contrast between those living in wealth, prosperity and freedom and those living in poverty or under oppression. Insofar as datong embodies a credible - or at least partially credible -- vision of the common good in human social existence, the vast distance between the datong world portrayed in Liyun and in Datong shu and the world today poses a challenge to our thinking, and impels us to think seriously about what is the common good and how far we are away from it. Is capitalism in the form it exists today consistent with the common good of humankind? Is socialism still a viable alternative, at least in the long run? The Chinese tradition of datong thinking is clearly relevant to our reflections today on these fundamental questions of social and political philosophy.

\footnotetext{
${ }^{9}$ Women however will have no right to abortion, as Kang believed that such a right may lead to population decline and endanger the survival of the human species (D190-193).
} 
To what extent, if any, does the ancient Chinese concept of datong and Kang's adaptation of it to the modern world provide a useful contribution to our thinking today about the common good? I would suggest a positive answer to this question. The Chinese character for tong in datong literally means "common" or "in common", while the Chinese character for $d a$ literally means "great". The key phrase tianxia weigong in the celebrated passage on datong in the Book of Rites may be translated as "all under Heaven is held in common" or "all under Heaven is publicly held”. The concept of datong is thus a concept that was intended by the ancient Chinese to embody a society whose organization is in accordance with the common good, or a society in which all members enjoy the good life. As pointed out above, all members of society share in the enjoyment of the benefits of social cooperation in the datong society. The welfare or well-being of all, including those who are weak, vulnerable or unable to take care of themselves, is well taken care of. Everyone is devoted to serving the common good instead of seeking only or mainly to benefit himself or herself or his or her family members. "They did not regard as parents only their own parents, or as sons only their own sons." Thus ren, benevolence, compassion, care or love for fellow human beings is extended to all. But this datong concept was developed more than two and a half millennia ago, and in the datong passage in the Book of Rites it was only used to refer to a more perfect society in the distant past which was no longer realizable - for only xiaokang was realizable in the contemporary world. Is datong a credible vision of the common good in the twenty-first century world?

The modern welfare state seeks to ensure a minimum standard of living and a reasonable quality of life for the weak, vulnerable, disadvantaged or underprivileged members of society. To this extent, it gives effect to the datong ideal. But the datong ideal goes further than guaranteeing minimum welfare to all. It envisages a kind of transformation of human motivation and human action from being self-centered to being altruistic. In the post-communist world of global capitalism, this core element of the datong vision would seem to be utopian and an impossible dream. Instead, what has apparently prevailed is Adam Smith's idea of the invisible hand in the market system which ensures that the self-interested actions of individuals or actors in the market will ultimately maximize the common good.

Kang's modernized version of datong is more optimistic regarding the possibility of human and social transformation. He introduces the idea of progress in history, drawing mainly upon the theory of the Three Ages in Chunqiu Gongyang. In the West, belief in progress was a mark of the Age of Enlightenment, which gave rise to social movements for progress which have continued to thrive up to this day. In Kang's philosophy, progress is possible, worth striving for, and an inherent dimension of human history. Progress includes not only material and scientific progress, but also moral progress (in terms of the increasing degree of realization of ren), cultural progress (in terms of increasing achievements in education and moral and intellectual 
cultivation), and social progress (in terms of the reduction of inequality, discrimination, injustice, exploitation and oppression, and advancing levels of freedom, autonomy, equal rights and democracy). The belief in and efforts to bring about progress in all these dimensions are still very much alive and well in the contemporary world. To this extent, Kang's datong philosophy still speaks to, and resonates in, our world today.

Even today, Kang's concepts of ren and of progress can still provide a persuasive and coherent theoretical foundation for practical struggles to fight for a better world in which the common good is better realized than in the world today or in the past history of humankind, and to fight for the global realization of human rights, justice, democracy and peace. Moreover, some of Kang's practical and concrete suggestions regarding a better world are still sound and yet to be realized today. For example, he understands that the ultimate solution to the sufferings of warfare can only be found in a rational and democratic system of governance at the global level. His proposals regarding women's rights and animal welfare are still in the process of being fought for in many parts of the world today.

What is more controversial in Kang's datong philosophy is the abolition of the family and of private property. Here it must first be pointed out that Kang was writing about datong in the distant future, and he made it clear that traditional family ethics have played a very important and positive role in traditional China and should continue to be respected now and in the foreseeable future. Indeed, he himself practiced the virtue of filial piety faithfully (Li, 1990, p.161). Secondly, Kang's rejection of the family and private property for the purpose of datong should be understood in the context of China's circumstances at the end of the nineteenth century, under which the extended family and clan operated in many cases as an hierarchical, authoritarian and oppressive institution which discriminated against women and suppressed their rights (or what we would today think of as their rights) in the name of morality (Li, 1990, pp. 158-161), and in which gross social and economic inequalities existed in society. With the benefit of hindsight, it might be said that Kang's prescriptions for remedying gender discrimination and social and economic inequality are too extreme, and that a fundamentally reformed family law (such that which exists in many parts of the modernized world today) and a social market economy are better solutions to the problems than the radical ones Kang envisaged.

\section{Conclusion}

Since the May Fourth Movement in the early twentieth century, many Chinese intellectuals abandoned Confucianism and other traditions of Chinese thought and became Westernized in their mode and content of thinking. The triumph of Marxism-Leninism in mainland China was, in a sense, a sign of the Westernization of the modern Chinese mind. However, as the radical Maoist excesses of the Cultural Revolution era came to be repudiated and as the People's Republic of China began to 
chart its new course of "reform and opening" three decades ago, many aspects of traditional Chinese thought have been quietly rehabilitated or gradually resurrected, or have regained the interest or even faith of Chinese intellectuals. The Chinese social and political philosophy of the twenty-first century need not and will not draw exclusively or primarily from Western sources. It is possible and likely that indigenous concepts and doctrines such as the datong thought discussed in this paper will have a role to play in shaping the Chinese social and political philosophy of the future.

Although this has never been officially recognized, there is in fact a surprising degree of convergence between some important ingredients of Kang Youwei's datong thought and the official ideology currently propagated by the Chinese Communist Party. According to this ideology, the Marxist vision of the communist society is still the highest ideal pursued by the Party and the Chinese people. However, this ideal can only be realized after socialist society has reached a high level of development. "The development and perfection of socialism is a long historical process." 10 China is, and will remain for a long time, in the "preliminary stage of socialism", when China as an "economically and culturally backward" nation needs to undergo "socialist modernization". ${ }^{11}$ The theory of the preliminary stage of socialism implies that full socialism cannot be practiced yet, and China may legitimately borrow capitalist techniques from the West. Not all the means of production will socialized and subject to public ownership, and there will still be economic inequality among the Chinese people. The idea that the ideals of socialism and communism will be realized, and will only be realized, in the course of a long process of historical development and social evolution thus converges with Kang's idea of historical progress and his vision of the datong world in which socialist or communist principles will be applicable in economic life.

The official view of the level of economic development of Chinese society now is that it has just reached the xiaokang level; it is hoped that by the centenary of the founding of the Chinese Communist Party (in 2021), China will have reached a "higher level of xiaokang society", and by the centenary of the establishment of the People's Republic of China (2049), China will have reached the level of a middle-level developed country and will have "basically completed its modernization". ${ }^{12}$ Thus the term xiaokang, which dates back more than two millennia ago to Liyun, is still being used today to refer to a second best level of development. The concept of "harmonious society" advocated in recent years by the Chinese Communist Party also draws on the Chinese tradition of thought, particularly the Confucian vision of social harmony and amicable social relationships.

\footnotetext{
${ }^{10}$ Author's own translation of a sentence in the $3^{\text {rd }}$ paragraph of the Preamble to the Constitution of the Chinese Communist Party (as amended in 2007).

${ }^{11}$ The quoted words are the author's translation of parts of the $9^{\text {th }}$ paragraph of the Preamble to the Constitution of the Chinese Communist Party (as amended in 2007).

${ }^{12}$ Ibid. ( $9^{\text {th }}$ paragraph of the Preamble).
} 
In the final analysis, the datong philosophy in Liyun and in Datong shu speaks not only to the Chinese people but to the whole of humankind. It is a philosophy which is universalist in its mode of thinking rather than particularistic and dependent on a particular culture or religion. It is a valuable contribution to the common heritage of mankind as far as thinking about the common good is concerned. Though ancient in origin, it still speaks to the needs and circumstances of, and challenges facing, the contemporary world. Though Chinese in origin, it is capable, as Kang Youwei has demonstrated, of entering into dialogue with the utilitarian, socialist and liberal traditions of thought in the modern West. It is to be hoped that datong thinking will continue to develop and contribute to the Chinese social and political philosophy of the twenty-first century.

\section{REFERENCES}

De Bary, W.T., Chan, Wing-tsit, \& Watson, B. (1960). Sources of Chinese Tradition, volume I. New York: Columbia University Press.

Chan Wing-Tsit (1967). 'K’ang Yu-wei and the Confucian Doctrine of Humanity,' in Lo Jung-pang (Ed.), pp. 355-374.

Chang Hao (Zhang Hao) (2002). Sixiang yu shidai (Thought and Times). Shanghai wenyi chubanshe.

Ding Yun (Ed.) (2009). Wusi yundong yu xiandai zhongguo (The May Fourth Movement and Modern China). Shanghai: Shanghai Renmin Press.

Hsiao Kung-chuan (1975). A Modern China and a New World: K’ang Yu-wei, Reformer and Utopian, 1858-1927. Seattle: University of Washington Press.

Lau, D.C. (trans.) (1992). Confucius, The Analects. Hong Kong: Chinese University Press, $2^{\text {nd }}$ edn.

Lau, D.C. (trans.) (1970). Mencius. London: Penguin Books.

Li Zehou (1990). Zhongguo jindai sixiang shilun (History of Chinese Modern Thought). Taipei: Fengyun shidai, revised edition.

Liang Chi-chao (1968). History of Chinese Political Thought During the Early Tsin Period, trans. L.T. Chen. Taipei: Cheng-wen Publishing Co; original edition London: Kegan Paul, 1930.

Lo Jung-pang (Ed.) (1967). K’ang Yu-wei: A Biography and a Symposium. Tucson: University of Arizona Press. 
Malmqvist, N.G.D. (Ma Yueran) (1991). 'The Difference between Chinese and Western Utopias from the Perspective of Datong shu,' Ershiyi shiji (Twenty-first Century), 5 (June 1991), 11-15 (in Chinese).

Mengzi wei, Liyun zhu, Zhongyong zhu (1987). Beijing: Zhonghua shuju (reprint prepared by Lou Yulie of the original classics).

Spence, J.D. (1981). The Gate of Heavenly Peace: The Chinese and Their Revolution, 1895-1980. New York: Viking Press.

Thompson, L.G. (trans.) (1958). Ta T'ung Shu: The One-World Philosophy of K'ang Yu-wei. London: George Allen \& Unwin.

Thompson, L.G. (1967). 'Ta-t'ung Shu and The Communist Manifesto,' in Lo Jung-pang (Ed.), pp. 341-354.

Wang Hui (2008). Xiandai Zhongguo sixiang de xingqi (The Rise of Modern Chinese Thought), vol. I, part 2. Beijing: Sanlian shudian, $2^{\text {nd }}$ edition.

Wang Rongzu (1988). Kangzhang helun (On Kang Youwei and Zhang Binglin). Taipei: Lianjing Press.

Zeng Yi (2009). 'Republicanism and Monarchy: Kang Youwei's Criticism and Reformation of Traditional Family, Clan and Politics,' in Ding Yun (Ed.), pp. 222-270.

Zhang Qijun (1988). Shudao yu datong (The Way of Forbearance and Datong). Taipei: Dongda.

Zhang Xiang (2009). 'Human Difference and the Reconstruction of the Way of Humanity: Kang Youwei’s Theory of Human Nature,' in Ding Yun (Ed.), pp. 89-123. 